\author{
Iwona Foryś \\ Barbara Batóg \\ Instytut Ekonometrii i Statystyki \\ Uniwersytet Szczeciński
}

\title{
Modelowanie aktywności nabywców mieszkań na rynku województwa zachodniopomorskiego
}

\section{Streszczenie}

Aktywność uczestników rynku mieszkaniowego jest ściśle związana z kondycją ekonomiczną gospodarstw domowych, a ta skorelowana jest z koniunkturą gospodarczą. Ogólna tendencja osłabienia aktywności na rynku nieruchomości w okresie dekoniunktury gospodarczej nie ma tego samego natężenia na wszystkich rynkach regionalnych. Celem badania było sprawdzenie intensywności zawierania umów kupna-sprzedaży mieszkań w różnych okresach koniunktury w województwie zachodniopomorskim. Badanie objęło analizę liczby zawieranych transakcji w czasie, z podziałem na podokresy koniunktury i dekoniunktury gospodarczej oraz z uwzględnieniem sezonowości liczby transakcji ogółem. Zbadana została również zależność liczby zawieranych umów kupna-sprzedaży na rynku mieszkaniowym od zmiennych charakteryzujących stan gospodarki, takich jak dochody gospodarstw domowych, przychody ze sprzedaży w sektorze przedsiębiorstw, liczba nabytych samochodów, wartość sprzedaży detalicznej i stopa bezrobocia. Analizy przeprowadzono w ujęciu miesięcznym dla województwa zachodniopomorskiego. Wykorzystano dane z rejestrów cen i wartości nieruchomości w starostwach powiatowych, NBP oraz statystyki publicznej. W pracy wykorzystano modele ekonometryczne ze zmiennymi opóźnionymi oraz modele trendu z sezonowością.

Słowa kluczowe: rynek nieruchomości, liczba transakcji, modele ekonometryczne, modele trendu z sezonowością. 


\section{Wprowadzenie}

Na podstawie intensywności sprzedaży mieszkań na danym rynku można określać aktywność uczestników tego segmentu rynku nieruchomości w określonej fazie cyklu koniunkturalnego. Rosnąca liczba zawieranych umów kupna-sprzedaży mieszkań świadczy o poprawie koniunktury, natomiast malejąca stanowi niepokojący sygnał na rynku mieszkaniowym [Foryś 2011]. Niezaspokojone potrzeby mieszkaniowe powinny powodować intensywny obrót mieszkaniami, warunkiem koniecznym jest jednak dostępność kapitału dla potencjalnych nabywców. Warunek ten jest ściśle związany z kondycją ekonomiczną gospodarstw domowych, a ta skorelowana jest $\mathrm{z}$ koniunkturą gospodarczą. Ponadto należy zauważyć, że ogólna tendencja osłabienia aktywności na rynku nieruchomości w okresie dekoniunktury gospodarczej nie ma tego samego natężenia na wszystkich rynkach regionalnych. Na danym rynku regionalnym umowy sprzedaży (zakupu) mieszkań również podlegają zjawisku sezonowości. Dzięki obserwacji rynku można stwierdzić nasilenie liczby transakcji w okresie wiosennym oraz jesiennym, co może wynikać także z cyklu inwestycyjnego w budownictwie mieszkaniowym (przeciętnie 18-22 miesiące). Należy ponadto uwzględnić opóźnione $\mathrm{w}$ czasie reakcje sprzedających i kupujących mieszkania w stosunku do ogólnych tendencji rynkowych - zwłaszcza na rynkach regionalnych w stosunku do tendencji globalnych [Batóg i Foryś 2011; Batóg i Foryś 2013].

Celem badania jest analiza i modelowanie intensywności zawierania umów kupna-sprzedaży mieszkań w okresie dekoniunktury na regionalnym rynku nieruchomości województwa zachodniopomorskiego w latach 2009-2013 oraz sezonowości liczby zawieranych umów. Badanie obejmuje analizę liczby zawieranych transakcji w czasie (dane miesięczne i kwartalne).

\section{Charakterystyka danych}

Dane dotyczące liczby transakcji pochodzą ze szczecińskiego systemu Walor, w którym znajdują się informacje na temat wszystkich umów rynkowych kupna-sprzedaży nieruchomości mieszkalnych (aktów notarialnych) zawartych na terenie województwa zachodniopomorskiego, zgromadzone przez rzeczoznawców majątkowych - sygnatariuszy systemu. Przyjmując założenie o rzetelnym gromadzeniu informacji, można uznać, że badanie jest pełne, a dane w analizowanym okresie były gromadzone w ten sam sposób. Dane obejmują transakcje zarówno na rynku pierwotnym, jak i na rynku wtórnym, z wyłączeniem umów nierynkowych, przy założeniu, że strony umowy były od siebie niezależne, nie działały pod przymusem, a mieszkanie było wyeksponowane na rynku dostatecznie długo. Dodatkowo podjęto próbę zbadania zależności liczby 
transakcji od wybranych zmiennych opisujących sytuację gospodarczą województwa zachodniopomorskiego oraz tych samych zmiennych, lecz opóźnionych.

W badaniu uwzględniono następujące zmienne:

$t$ - zmienna czasowa (miesiące, kwartały),

$y_{t}-$ liczba transakcji,

$z_{1 t}$ - produkcja sprzedana budownictwa (w $\mathrm{mln} \mathrm{z}$ ),

$z_{2 t}$ - produkcja sprzedana budownictwa - budowa budynków (w mln zł),

$z_{3 t}$ - przeciętne miesięczne wynagrodzenie brutto (w zł),

$z_{4 t}$ - przeciętne miesięczne wynagrodzenie brutto w budownictwie (w zl),

$z_{5 t}-$ pracujący w sektorze przedsiębiorstw,

$z_{6 t}-$ pracujący w budownictwie,

$z_{7 t}-$ pracujący w budownictwie - budowa budynków,

$z_{8 t}$ - przeciętne zatrudnienie $\mathrm{w}$ budownictwie,

$z_{9 t}$ - sprzedaż detaliczna ogółem (w mln zł),

$z_{10 t}$ - sprzedaż pojazdów samochodowych, motocykli, części (analogiczny okres roku poprzedniego $=100$ ),

$z_{11 t}$ - mieszkania oddane do użytkowania - budownictwo indywidualne,

$z_{12 t}$ - mieszkania oddane do użytkowania - przeznaczone na sprzedaż lub wynajem,

$z_{13 t}$ - stopa bezrobocia rejestrowanego (w \%).

\section{Koncepcja badania}

W pierwszej kolejności analizie poddano kształtowanie się miesięcznej oraz kwartalnej liczby transakcji w rozpatrywanym okresie. W przypadku liczby transakcji zbadano występowanie trendu oraz sezonowości. W tym celu oszacowano model trendu liniowego ze stałą sezonowością (1) dla danych w postaci szeregów czasowych kwartalnych oraz miesięcznych [Zeliaś 1997, Judge i in. 1985]:

$$
y_{t}=\delta_{0}+\delta_{1} t+\sum_{k=1}^{m} d_{0 k} Q_{k t}+U_{t},
$$

gdzie:

$y_{t}$ - zmienna objaśniana,

$t$-zmienna czasowa,

$\delta_{0}, \delta_{1}$ - parametry trendu liniowego,

$m$ - liczba sezonów (4 dla danych kwartalnych, 12 dla danych miesięcznych),

$k$ - numer sezonu,

$Q_{k t}$-zmienna zerojedynkowa ( 1 dla sezonu $k, 0$ dla pozostałych),

$d_{0 k}$ - parametry sezonowe,

$U_{t}-$ składnik losowy. 
W następnej kolejności wyznaczono współczynniki korelacji liniowej Pearsona pomiędzy miesięczną liczbą transakcji a potencjalnymi zmiennymi objaśniającymi $z_{1 t}-z_{13 t}$ oraz ich opóźnieniami. Współczynniki te były podstawą do wyboru ostatecznych zmiennych objaśniających w liniowym modelu ekonometrycznym (2) [Maddala 2006, Johnston 1991]:

$$
y_{t}=\alpha_{0}+\sum_{i=1}^{r} \alpha_{i} X_{i t}+U_{t}
$$

gdzie:

$y_{t}$ - zmienna objaśniana,

$X_{i t}-i$-ta zmienna objaśniająca,

$\alpha_{0}, \alpha_{i}-$ parametry strukturalne,

$r$ - liczba zmiennych objaśniających,

$U_{t}$ - składnik losowy.

\section{Wyniki empiryczne}

W pierwszej kolejności badaniu podlegała kwartalna liczba transakcji w województwie zachodniopomorskim. Kształtowanie się tej zmiennej w rozpatrywanym okresie przedstawiono na rys. 1 .

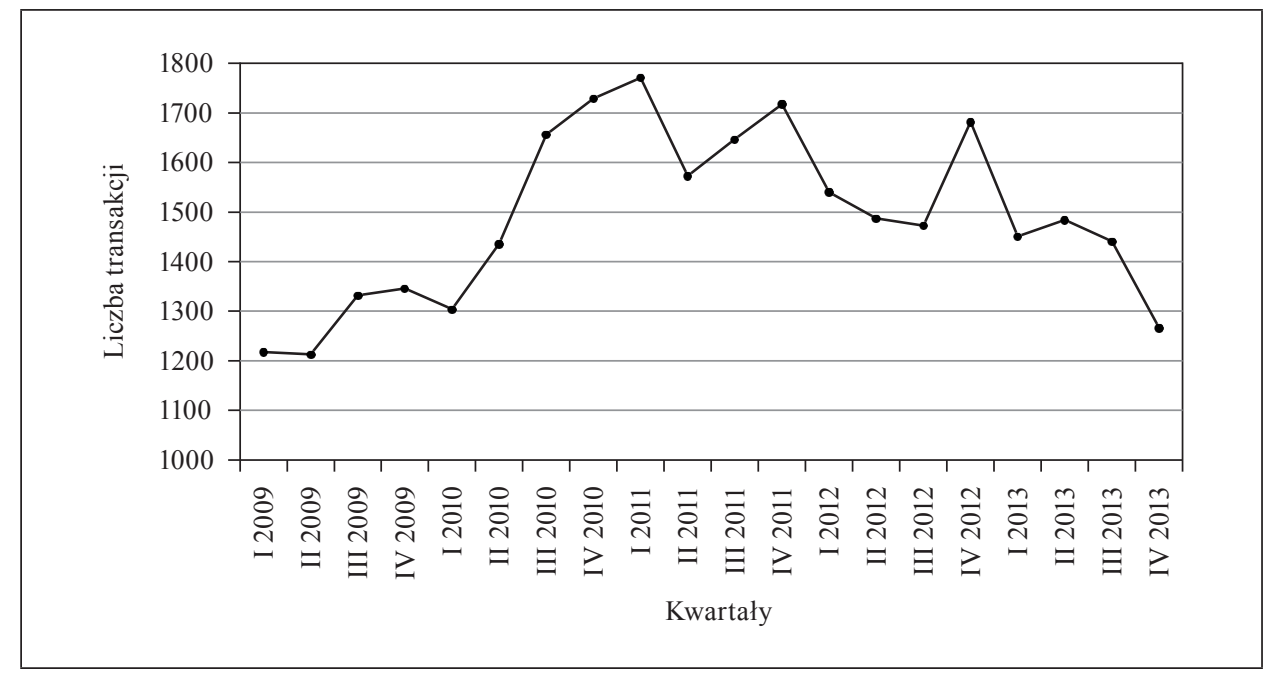

Rys. 1. Liczba transakcji w poszczególnych kwartałach lat 2009-2013

Źródło: obliczenia własne na podstawie danych z aktów notarialnych. 
Kwartalna liczba transakcji w okresie od I kwartału 2009 r. do II kwartału 2010 r. charakteryzowała się znacznie niższym poziomem niż w okresie od III kwartału 2010 r. do III kwartału 2013 r. Z tego też względu oszacowano model trendu liniowego ze stałą sezonowością (1) na podstawie danych tylko z drugiego okresu. Wyniki oszacowania zamieszczono w tabeli 1. Należy ponadto nadmienić, że w modelu nie został uwzględniony IV kwartał 2013 r., gdyż liczba transakcji w tym kwartale znacząco spadła i na chwilę obecną nie można rozstrzygnąć, czy jest to nowa tendencja, czy w kwartale tym nie zostały jeszcze uwzględnione wszystkie transakcje.

Tabela 1. Oszacowanie modelu trendu liniowego ze stałą sezonowością kwartalną

\begin{tabular}{|c|c|c|c|c|}
\hline \multirow{2}{*}{ Zmienna } & \multicolumn{4}{|c|}{ Liczba transakcji } \\
\cline { 2 - 5 } & Ocena parametru & Błąd standardowy & Statystyka $t$ & Poziom $p$ \\
\hline Wyraz wolny & 1847,701 & 63,564 & 29,068 & 0,000 \\
\hline$t$ & $-19,705$ & 4,702 & $-4,1911$ & 0,003 \\
\hline$Q_{1 t}$ & $-4,208$ & $-^{\text {a }}$ & $--^{\text {a }}$ & $-^{\text {a }}$ \\
\hline$Q_{2 t}$ & $-57,170$ & 31,219 & $-1,831$ & 0,104 \\
\hline$Q_{3 t}$ & $-37,042$ & 28,114 & $-1,318$ & 0,224 \\
\hline$Q_{4 t}$ & 98,420 & 31,219 & 3,153 & 0,014 \\
\hline \multicolumn{5}{|c|}{$R^{2}=0,811, F(4,8)=8,57, p=0,005, D W=2,868$} \\
Błąd standardowy estymacji: 62,38 \\
\hline
\end{tabular}

a parametr dla pierwszego kwartału został wyznaczony z warunku pobocznego, nie można zatem ocenić jego istotności.

Źródło: obliczenia własne.

Oszacowany model trendu liniowego ze stałą sezonowością kwartalną charakteryzuje się wysokim dopasowaniem do danych, przewagą wyjaśnionej wariancji zmiennej objaśnianej nad wariancją niewyjaśnioną oraz niskim błędem standardowym estymacji. Wartość statystyki Durbina-Watsona nie pozwala wnioskować o występowaniu bądź niewystępowaniu zjawiska autokorelacji, dlatego dodatkowo przeprowadzono test Breuscha-Godfreya [Wooldridge 2013]. Otrzymana wartość statystyki testowej nie daje podstaw do odrzucenia hipotezy o braku autokorelacji (poziom istotności 0,05). Kwartalna liczba transakcji w drugiej części badanego okresu charakteryzuje się malejącym trendem liniowym parametr przy zmiennej czasowej $t$ jest istotny (na poziomie istotności 0,05 ) oraz ujemny. Dla tej zmiennej występuje również sezonowość - parametr przy zmiennej $Q_{4 t}$ jest istotny (na poziomie istotności 0,05 ) oraz dodatni, co świadczy o zwiększonej liczbie transakcji zawieranych w czwartych kwartałach analizowanych lat. Ze względu na brak możliwości oszacowania modelu (1) w zapisanej 
postaci, z modelu tego usuwa się jedną ze zmiennych zerojedynkowych. Zwykle jest to zmienna reprezentująca ostatni sezon. W przypadku liczby transakcji okazało się, że po usunięciu zmiennej zerojedynkowej reprezentującej ostatni sezon, parametry sezonowe nie były istotne. Zdecydowano się zatem na usunięcie z modelu zmiennej reprezentującej sezon pierwszy - ze względu na specyfikę rynku nieruchomości właśnie w końcu roku można było spodziewać się istotnego parametru sezonowego.

W drugiej kolejności badaniu podlegała miesięczna liczba transakcji w województwie zachodniopomorskim. Kształtowanie się tej zmiennej w rozpatrywanym okresie przedstawiono na rys. 2.

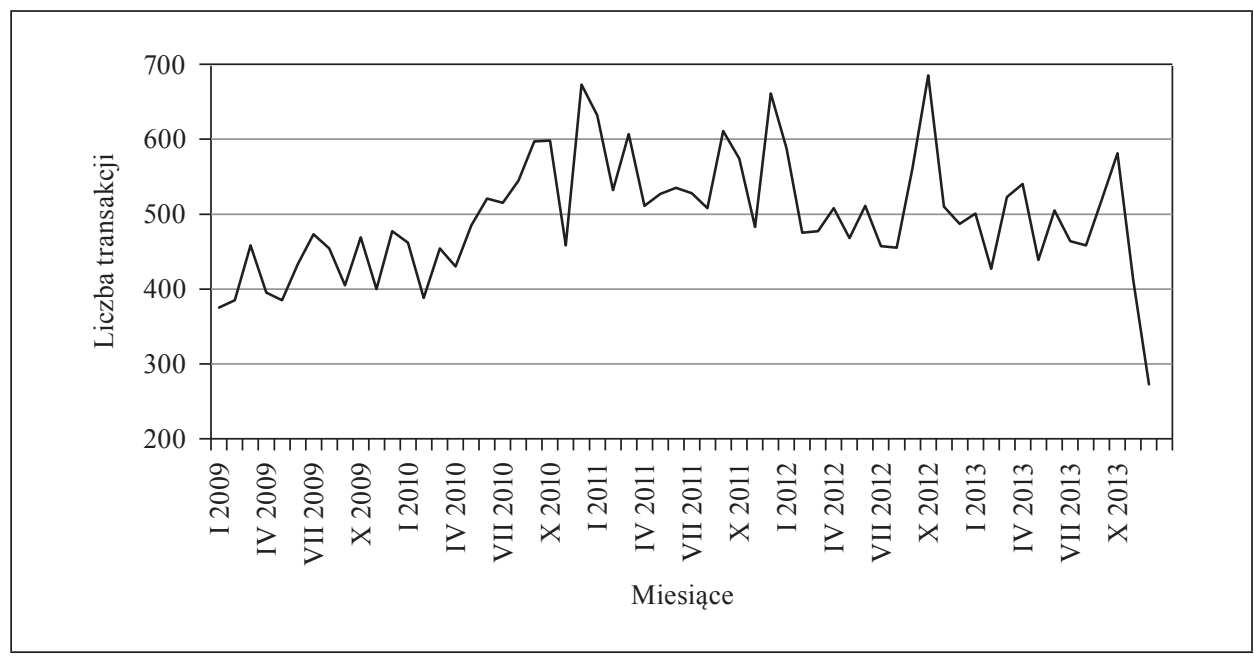

Rys. 2. Liczba transakcji w poszczególnych miesiącach lat 2009-2013

Źródło: obliczenia własne na podstawie danych z aktów notarialnych.

Miesięczna liczba transakcji w okresie od stycznia 2009 r. do czerwca 2010 r. charakteryzowała się znacznie niższym poziomem niż w okresie od lipca $2010 \mathrm{r}$. do listopada 2013 r. Z tego też względu podobnie jak w przypadku kwartalnej liczby transakcji model został oszacowany na podstawie danych z drugiego okresu. Należy ponadto nadmienić, że w modelu nie został uwzględniony grudzień 2013 r., gdyż liczba transakcji w tym miesiącu znacząco spadła i na chwilę obecną nie można rozstrzygnąć, czy jest to nowa tendencja, czy nie zostały jeszcze uwzględnione wszystkie transakcje w grudniu. Wyniki oszacowania zamieszczono w tabeli 2. 
Tabela 2. Oszacowanie modelu trendu liniowego ze stałą sezonowością miesięczną

\begin{tabular}{|c|c|c|c|c|}
\hline \multirow{2}{*}{ Zmienna } & \multicolumn{4}{|c|}{ Liczba transakcji } \\
\cline { 2 - 5 } & Ocena parametru & Błąd standardowy & Statystyka $t$ & Poziom $p$ \\
\hline Wyraz wolny & 614,188 & 23,037 & 26,661 & 0,000 \\
\hline$t$ & $-2,204$ & 0,565 & $-3,899$ & 0,001 \\
\hline$Q_{1 t}$ & 41,029 & $-{ }^{\mathrm{a}}$ & $-{ }^{\mathrm{a}}$ & $-^{\mathrm{a}}$ \\
\hline$Q_{2 t}$ & $-52,433$ & 23,313 & $-2,249$ & 0,033 \\
\hline$Q_{3 t}$ & 7,438 & 23,306 & 0,319 & 0,752 \\
\hline$Q_{4 t}$ & $-6,358$ & 23,313 & $-0,273$ & 0,787 \\
\hline$Q_{5 t}$ & $-45,821$ & 23,334 & $-1,964$ & 0,060 \\
\hline$Q_{6 t}$ & $-4,617$ & 23,368 & $-0,198$ & 0,845 \\
\hline$Q_{7 t}$ & $-41,637$ & 20,490 & $-2,032$ & 0,052 \\
\hline$Q_{8 t}$ & $-38,933$ & 20,466 & $-1,902$ & 0,067 \\
\hline$Q_{9 t}$ & 43,771 & 20,458 & 2,139 & 0,041 \\
\hline$Q_{10 t}$ & 83,475 & 20,466 & 4,079 & 0,000 \\
\hline$Q_{11 t}$ & $-58,071$ & 20,490 & $-2,834$ & 0,008 \\
\hline$Q_{12 t}$ & 72,159 & 23,368 & 3,088 & 0,005 \\
\hline \multicolumn{5}{|c|}{$R^{2}=0,719, F(12,28)=5,97, p<0,000, D W=1,691$} \\
\end{tabular}

${ }^{a}$ parametr dla pierwszego miesiąca został wyznaczony z warunku pobocznego, zatem nie można ocenić jego istotności.

Źródło: obliczenia własne.

Oszacowany model trendu liniowego ze stałą sezonowością miesięczną charakteryzuje się wysokim dopasowaniem do danych (choć niższym niż w przypadku danych kwartalnych), przewagą wyjaśnionej wariancji zmiennej objaśnianej nad wariancją niewyjaśnioną oraz niskim błędem standardowym estymacji. Podobnie jak w przypadku modelu dla danych kwartalnych wartość statystyki Durbina-Watsona nie pozwala wnioskować o występowaniu bądź niewystępowaniu zjawiska autokorelacji. Dla tego modelu również przeprowadzono test Breuscha-Godfreya [Wooldridge 2013]. Otrzymana wartość statystyki testowej nie daje podstaw do odrzucenia hipotezy o braku autokorelacji (poziom istotności 0,05). Miesięczna liczba transakcji w drugiej części badanego okresu charakteryzuje się malejącym trendem liniowym - parametr przy zmiennej czasowej $t$ jest istotny oraz ujemny. Dla tej zmiennej występuje także sezonowość - parametry przy zmiennych $Q_{2 t}, Q_{9 t}, Q_{10 t}, Q_{11 t}, Q_{12 t}$ są istotne (na poziomie istotności 0,05$)$. Ze znaków istotnych parametrów sezonowych wynika, że w drugiej części badanego okresu liczba transakcji w lutym oraz w listopadzie kształtowała 
się poniżej trendu, natomiast we wrześniu, październiku i grudniu - powyżej trendu. Podobnie jak w przypadku oszacowania modelu dla danych kwartalnych z modelu usunięto zmienną zerojedynkową reprezentującą pierwszy sezon.

W kolejnej części badania obliczono najpierw współczynniki korelacji liniowej Pearsona pomiędzy liczbą transakcji a wybranymi zmiennymi ekonomicznymi oraz ich opóźnieniami (rys. 3).

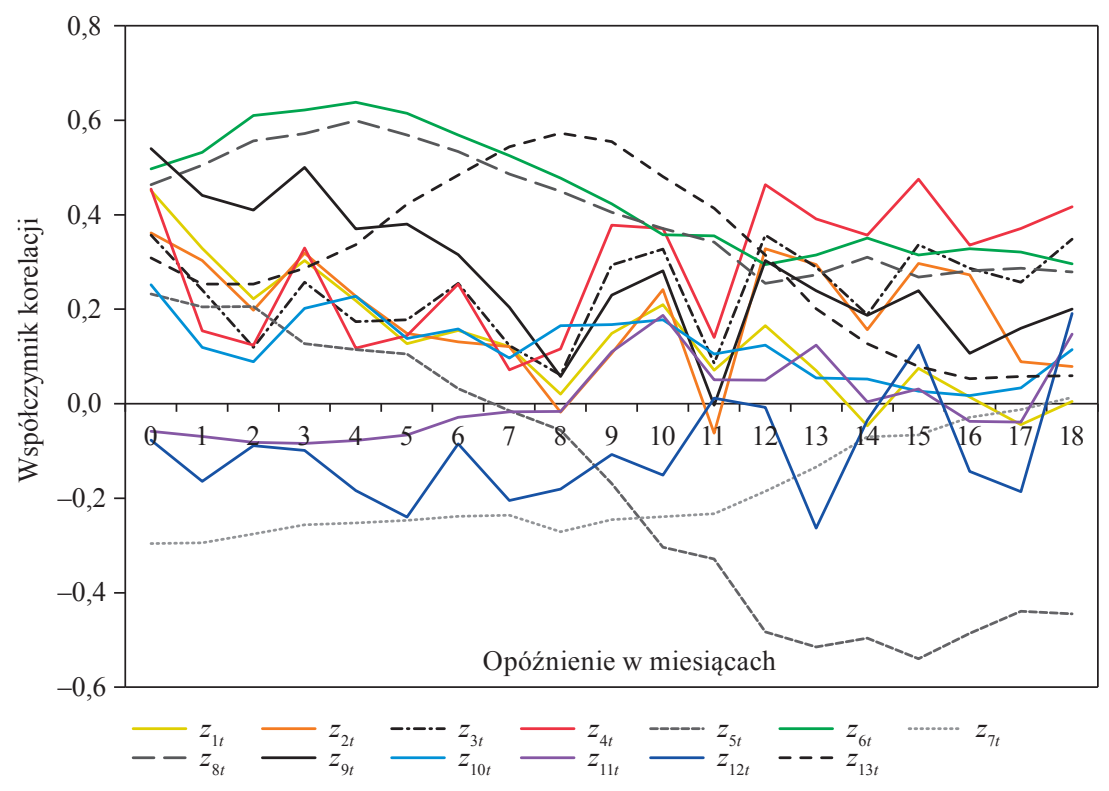

Rys. 3. Współczynniki korelacji pomiędzy liczbą transakcji a zmiennymi ekonomicznymi oraz ich opóźnieniami Źródło: obliczenia własne.

Dla większości analizowanych potencjalnych zmiennych objaśniających oraz ich opóźnień współczynniki korelacji mieściły się w przedziale od -0,3 do 0,4. Wyjątkiem są zmienne: $z_{6 t}$ - pracujący w budownictwie oraz $z_{8 t}$ - przeciętne zatrudnienie w budownictwie przy małych opóźnieniach, $z_{13 t}$ - stopa bezrobocia rejestrowanego przy środkowych opóźnieniach, $z_{4 t}$ - przeciętne miesięczne wynagrodzenie brutto $\mathrm{w}$ budownictwie - przy dużych opóźnieniach, oraz $z_{5 t}-$ pracujący w sektorze przedsiębiorstw - dość silna korelacja ujemna przy dużych opóźnieniach.

Następnie oszacowano model liniowy zależności miesięcznej liczby transakcji od tych zmiennych, dla których oszacowany model charakteryzował się najlep- 
szymi własnościami. Ostateczne zmienne objaśniające wybrano, kierując się obliczonymi współczynnikami korelacji oraz wspomagając je regresją krokową postępującą. Procedura postępowania była następująca: w pierwszej kolejności do modelu wybrano pierwszą zmienną objaśniającą z opóźnieniem, dla którego współczynnik korelacji ze zmienną objaśnianą był największy (było to opóźnienie 0), następnie dla drugiej zmiennej objaśniającej sprawdzono, czy poprawia się istotnie jakość modelu przy jej wprowadzaniu z kolejnymi opóźnieniami (dla każdego opóźnienia osobno), a dalsze postępowanie przeprowadzono dla kolejnych zmiennych objaśniających tak jak dla drugiej. Oszacowanie wybranego do prezentacji modelu zamieszczono w tabeli 3.

Tabela 3. Oszacowanie modelu liniowego dla miesięcznej liczby transakcji

\begin{tabular}{|c|c|c|c|c|}
\hline \multirow{2}{*}{ Zmienna } & \multicolumn{4}{|c|}{ Liczba transakcji } \\
\cline { 2 - 5 } & $\begin{array}{c}\text { Ocena } \\
\text { parametru }\end{array}$ & $\begin{array}{c}\text { Błąd } \\
\text { standardowy }\end{array}$ & Statystyka $t$ & Poziom $p$ \\
\hline Wyraz wolny & 1392,364 & 400,980 & 3,472 & 0,001 \\
\hline$z_{1 t}$ & 0,136 & 0,029 & 4,769 & 0,000 \\
\hline$z_{5 t}$ - opóźnienie 3 miesiące & $-0,009$ & 0,003 & $-3,239$ & 0,002 \\
\hline$z_{9 t}$ - opóźnienie 1 miesiąc & 0,349 & 0,094 & 3,706 & 0,000 \\
\hline$z_{12 t}-$ opóźnienie 1 miesiąc & $-0,083$ & 0,022 & $-3,693$ & 0,001 \\
\hline \multicolumn{5}{|c|}{$R^{2}=0,519, F(4,54)=14,58, p<0,000, D W=1,616$} \\
\end{tabular}

Źródło: obliczenia własne na podstawie danych z aktów notarialnych.

W modelu zaprezentowanym w tabeli 3 zmienne objaśniające to: $z_{1 t}-$ produkcja sprzedana budownictwa (bez opóźnienia), $z_{5 t}$ - pracujący w sektorze przedsiębiorstw (opóźnienie 3 miesiące), $z_{9 t}$ - sprzedaż detaliczna ogółem (opóźnienie 1 miesiąc), $z_{12 t}$ - mieszkania oddane do użytkowania - przeznaczone na sprzedaż lub wynajem (opóźnienie 1 miesiąc). Wszystkie te zmienne charakteryzowały się istotnymi parametrami. Podobnie jak w przypadku modeli trendu z sezonowością wartość statystyki Durbina-Watsona nie pozwala wnioskować o występowaniu bądź niewystępowaniu zjawiska autokorelacji. Również dla tego modelu przeprowadzono test Breuscha-Godfreya [Wooldridge 2013]. Otrzymana wartość statystyki testowej nie daje podstaw do odrzucenia hipotezy o braku autokorelacji (poziom istotności 0,05 ). W celu wyeliminowania możliwości występowania regresji pozornej porównano wartość statystyki Durbina-Watsona ze współczynnikiem dopasowania $R^{2}$. Okazało się, że wartość statystyki Durbina-Watsona $(1,616)$ była znacznie wyższa niż współczynnik dopasowania $R^{2}(0,519)$. Taka zależność potwierdza brak występowania regresji pozornej [Kośko, Osińska 
i Stempińska 2007]. Dopasowanie modelu (najlepszego) na poziomie 0,519 jest raczej umiarkowane, pomimo tego, że oszacowany model charakteryzował się przewagą wariancji wyjaśnionej nad niewyjaśnioną oraz stosunkowo niskim błędem standardowym estymacji (współczynnik zmienności resztowej wyniósł tylko $10,7 \%)$.

\section{Wnioski}

W ujęciu kwartalnym liczba transakcji charakteryzowała się trendem liniowym oraz stałą sezonowością. W analizowanym okresie liczba transakcji spadała - oszacowany współczynnik trendu jest ujemny. W czwartym kwartale, w którym liczba transakcji wzrasta, składnik sezonowy jest istotny oraz dodatni.

W ujęciu miesięcznym liczba transakcji charakteryzowała się trendem liniowym oraz stałą sezonowością. W analizowanym okresie liczba transakcji spadała - oszacowany współczynnik trendu jest ujemy. Składniki sezonowe są istotne i ujemne w lutym i listopadzie, natomiast istotne i dodatnie - we wrześniu, październiku i grudniu.

Współczynniki korelacji pomiędzy liczbą transakcji a zmiennymi ekonomicznymi oraz ich opóźnieniami w większości przypadków mieszczą się w przedziale $(-0,2 ; 0,4)$, co oznacza słabą zależność.

Do wyboru zmiennych objaśniających wykorzystano procedurę regresji krokowej (postępującej). W efekcie do modelu jako zmienne objaśniające weszły: produkcja sprzedana budownictwa (bez opóźnienia), pracujący w sektorze przedsiębiorstw (opóźnienie 3 miesiące), sprzedaż detaliczna ogółem (opóźnienie 1 miesiąc) oraz mieszkania oddane do użytkowania - przeznaczone na sprzedaż lub wynajem (opóźnienie 1 miesiąc). Mimo iż parametry stojące przy zmiennych okazały się istotne, dopasowanie modelu nie jest zbyt wysokie, co może oznaczać, że z otoczenia gospodarczego nie płyną jednoznaczne sygnały mające wpływ na liczbę zawieranych umów kupna-sprzedaży.

Tendencje w zakresie liczby transakcji zawartych na terenie województwa zachodniopomorskiego potwierdzają specyfikę rynku mieszkaniowego na tle całego rynku nieruchomości. Na rynku mieszkaniowym niezaspokojone potrzeby powodują odmienne, nie zawsze skorelowane z sytuacją gospodarczą, zachowania kupujących. 


\section{Literatura}

Batóg B., Foryś I. [2011], Modele logitowe w analizie transakcji na warszawskim rynku mieszkaniowym, „Studia i Materiały Towarzystwa Naukowego Nieruchomości”, vol. 19 , nr 3.

Batóg B., Foryś I. [2013], Zastosowanie modeli zmiennych jakościowych do badania wpływu cech mieszkań na cenę rynkowa kwalifikująca je do finansowania w programie „Rodzina na swoim”, „Wiadomości Statystyczne”, nr 5.

Foryś I. [2011], Społeczno-gospodarcze determinanty rozwoju rynku mieszkaniowego w Polsce. Ujęcie ilościowe, Wydawnictwo Naukowe Uniwersytetu Szczecińskiego, Szczecin.

Johnston J. [1991], Econometric Methods, McGraw-Hill Book Company, New York.

Judge G.G., Griffiths W.E., Hill R.C., Lutkepohl H., Lee T.-C. [1985], The Theory and Practice of Econometrics, John Wiley and Sons, New York.

Kośko M., Osińska M., Stempińska J. [2007], Ekonometria współczesna, Wydawnictwo „Dom Organizatora”, Toruń.

Maddala G.S. [2006], Ekonometria, Wydawnictwo Naukowe PWN, Warszawa.

Wooldridge J.M. [2013], Introductory Econometrics. A Modern Approach, South-Western, Mason.

Zeliaś A. [1997], Teoria prognozy, PWE, Warszawa.

\section{Modeling the Activity of Apartment Buyers on the Zachodniopomorskie Voivodship Market \\ (Abstract)}

The activity of participants on the housing market is related to the economic situation of the households, which itself is related to the overall business climate. The tendency for activity on the housing market to weaken during economic recession is not the same on different local markets. The aim of the paper is to analyse the intensity of the purchase-sale transactions during different business cycles in the West Pomeranian voivodship. The research includes analysis of the number of transactions in time, split into different business cycles or different seasons. The dependency of the number of purchase-sale transactions on the housing market and economic variables such as household income, sales revenue, retail sales and the unemployment rate is also analysed. The econometric models with lagged variables and time series models with seasonality are also applied. The data concerning transactions come from the real estate price and value registers from the District Governor's Office, the National Bank of Poland and the Central Statistical Office.

Keywords: real estate market, number of transactions, econometric models, time series models with seasonality. 